\title{
Susceptibility of Aedes aegypti (L) to the insect growth regulators diflubenzuron and methoprene in Uberlândia, State of Minas Gerais
}

\author{
Susceptibilidade de Aedes aegypti (L) aos reguladores de crescimento \\ de insetos diflubenzuron e methoprene em Uberlândia, \\ Estado de Minas Gerais
}

\author{
Juliana Junqueira da Silva ${ }^{1}$ and Júlio Mendes $^{1}$
}

\begin{abstract}
Aedes aegypti (L) (Diptera: Culicidae) was reared in several concentrations of diflubenzuron and methoprene under laboratory conditions in Uberlândia, State of Minas Gerais, southeastern Brazil. Characteristics such as LC50 and LC95, the susceptibility of immature stages of different ages to these insect growth regulators and their residual effects were studied. The LC50 and LC95 of diflubenzuron and methoprene were 5.19 and 12.24 ppb; 19.95 and 72.08 ppb, respectively. While diflubenzuron caused great mortality in all larval instars, methoprene was more effective when the mosquito was exposed from the start of the fourth larval instar onwards. Commercial concentrations of these two insect growth regulators close to LC95 presented greater residual activity than did their respective technical formulations. The parameters were compared with those obtained elsewhere. The characteristics investigated here indicate that these insect growth regulators are effective alternatives for controlling the dengue vector in the Uberlândia region.
\end{abstract}

Key-words: Aedes aegypti. Insect growth regulators. Diflubenzuron. Methoprene. Residual effect.

\section{RESUMO}

Aedes aegypti (L) (Diptera: Culicidae) foi criado em várias concentrações de diflubenzuron e methoprene sob condições de laboratório em Uberlândia, Minas Gerais, sudeste do Brasil. Foram estudados aspectos tais como, CL50 e CL95, suscetibilidade de estágios imaturos de diferentes idades a estes insect growth regulators e seu efeito residual. As CL50 e CL95 de diflubenzuron e methoprene foram: 5,19 e 12,24ppb; 19,95 e 72,08ppb, respectivamente. Enquanto diflubenzuron causou grande mortalidade em todos os estádios larvais, methoprene causou maior mortalidade quando o mosquito foi exposto a partir do início do quarto estádio larval. As concentrações comerciais dos dois insect growth regulators próximas às CL95 mostraram maior atividade residual que suas respectivas formulações técnicas. Os parâmetros são comparados com aqueles obtidos em outros locais. Os aspectos aqui investigados indicam estes insect growth regulators como alternativas efetivas para o controle do vetor da dengue na região de Uberlândia.

Palavras-chaves: Aedes aegypti. Insect growth regulators. Diflubenzuron. Methoprene. Efeito residual.

The insect growth regulators (IGRs) diflubenzuron, which is a chitin synthesis inhibitor (CSI), and methoprene, which is a juvenile hormone analog (JHA), are effective additional tools of public health and veterinary importance for controlling pests and disease vectors ${ }^{20} 2130$. These IGRs are selective insecticides and nontoxic to humans and other vertebrates ${ }^{132132}$.

Aedes aegypti (L) is the urban yellow fever and dengue vector in several tropical countries. Fighting the vector has been the main strategy for controlling these diseases. Dengue is the subject of one of the major ongoing public health control programs in Brazil ${ }^{12}$. The State of Minas Gerais (MG), located in southeastern Brazil, presents numerous cases of dengue, and the City of Uberlândia contributes significantly to the numbers in this state ${ }^{12}$.

Brazilian vector control campaigns mainly use the organophosphate temephos. Resistance to organophosphate pesticides has been described in many countries ${ }^{262833}$, including

\footnotetext{
1. Laboratório de Entomologia, Instituto de Ciências Biomédicas, Universidade Federal de Uberlândia, Uberlândia, MG. This work was partially supported by Brazilian funding agency, CAPES.

Address to: Prof. Júlio Mendes. Laboratório de Entomologia/ICBIM/UFU. Campus Umuarama, Caixa Postal 593, 38400-902 Uberlândia, MG. Tel: $55343218-2198$

E-mail: jmendes@ufu.br

Recebido para publicação em 4/12/2006

Aceito em 01/11/2007
} 
Brazil $^{41719}$. Following the recommendations of the World Heath Organization, the Brazilian Health Ministry has proposed that mosquito breeding grounds should be treated with methoprene, among other control tools, wherever the vector displays tolerance to temephos ${ }^{11}$. Despite the growing number of reports of Aedes aegypti resistance to temephos in Brazil, evaluations of IGRs and other tools for controlling this mosquito in this country are still incipient. In the present report, Aedes aegypti susceptibility to diflubenzuron and methoprene was investigated in Uberlândia based on studying characteristics such as LC50 and LC95, the susceptibility of immature stages of different ages to these IGRs, and the residual activity of these regulators.

\section{MATERIAL AND METHODS}

Collection and rearing of mosquito specimens. Aedes aegypti specimens were collected using egg-collecting traps (ovitraps) in three neighborhoods in the city of Uberlândia from April 2003 to March 2005. The traps were taken to the Parasitology Laboratory of the Institute of Biomedical Sciences, Federal University of Uberlândia, in Uberlândia, MG. Hatched larvae were reared in glass flasks containing water with $30 \mathrm{mg}$ of macerated mouse food (Nuvilab CR1, Nuvital ${ }^{\circledR}$ S/A, Brazil) and covered with organza. As the imagoes emerged, they were removed to entomological cages containing sugary water, ovitraps, and the females obtained their blood meals by sucking on mice. The progenies were kept in separate cages and used as egg sources to carry out susceptibility tests. To maintain the colony's genetic pool similar to that of the outdoor population throughout the experimental period, eggs were collected periodically outdoors and the insects were reared to adulthood. Their progeny (F1) was transferred to the cages containing mosquitoes, from which eggs were removed and used in the assays. All larvae used in the assays were kept in flasks in a BOD incubator at $25 \pm 1^{\circ} \mathrm{C}$, $70 \pm 10 \%$ humidity and $12 \mathrm{~h} / 12 \mathrm{~h}$ photoperiods. The numbers of individuals in each flask $(n=20)$ and replicates $(n=6)$ were the same in all assays. The mortality of mosquitoes and the emergence of imagoes were monitored daily and only emerging mosquitoes whose bodies were completely devoid of the exuviae were recorded as alive.

Preparation of solutions. Stock solutions of technical diflubenzuron 99.4\% (Champion Farmoquímico Ltda, Brazil) and methoprene 94.7\% (Novartis Saúde Animal Ltda, Brazil) were prepared using PA acetone as the solvent. Aliquots of the stock solutions were then added to distilled water to obtain the desired concentrations. In the assays for residual effects, solutions of both the technical products and their commercially formulated counterparts were tested.

Accessing LC50 and LC95. Concentrations of 2 to 20 $\mathrm{ppb}$ of diflubenzuron and of 5 to $300 \mathrm{ppb}$ of methoprene were prepared. To test each of these concentrations, early fourth instar larvae were placed in flasks containing $250 \mathrm{ml}$ of aqueous solutions of IGRs. The flasks of the control group contained water, with the respective acetone aliquots used in the tests. Thirty $\mathrm{mg}$ of macerated mouse food were then placed in each flask of both groups. The mortality data were subjected to Probit regression analysis $^{9}$ using the demonstration version of Minitab ${ }^{\circledR}$ release 14 for Windows (http://www.minitab.com/products/minitab/ $14 / \mathrm{htm})$. The mortality in the control group was taken to be the natural response rate To test how well the model fitted the data, the Pearson chi-square goodness-of-fit and deviance tests were applied. To obtain a better fit after residual analysis, two of the data points initially used in the regression analysis were discarded. The respective slope lines were also compared using the chi-square test.

Insect growth regulators effects on immature individuals of different ages. Larvae of ages $2 \mathrm{~h}, 24 \mathrm{~h}, 48 \mathrm{~h}, 72 \mathrm{~h}$ (early fourth instar), 96h, 120h and 144h and pupae were reared in the respective aqueous solutions of IGRs, at close to LC95: diflubenzuron $10 \mathrm{ppb}$ and methoprene $70 \mathrm{ppb}$. These assays were carried out twice under experimental conditions similar to those described above. Inferences were made about the susceptibility of groups of various ages, with adjustment of the mortality data according to the respective controls ${ }^{1}$.

Residual effects of insect growth regulators. Aqueous solutions of diflubenzuron 10ppb and methoprene 70ppb were prepared in plastic flasks. Test flasks and their respective controls containing one liter of solution were prepared for each of the respective technical (Tf) and commercial (Cf) IGR formulations: Altosid® XR-G 1.5\% a.i. (Novartis Saúde Animal Ltda, Brazil) and Difly® 25\% a.i. (Champion Farmoquímico Ltda, Brazil). Thereafter, the flask was loaded with 20 early fourth instar larvae. Dead immature stages and imagoes that emerged were removed from the flasks daily and new groups of larvae were placed in the flasks after the respective control group members emerged. At the same time, any remaining larvae and/or pupae belonging to the experimental groups were removed from the flasks and recorded as dead ${ }^{24}$. This procedure was applied until the proportion of imagoes emerging in the experimental groups was close to that observed in the control group.

\section{RESULTS}

In each assay, the control groups presented imago emergence of over $90 \%$. Both of the goodness-of-fit tests used indicated that the provisional lines from regression analysis fitted well to the diflubenzuron $(\mathrm{p}=0.777 ; \mathrm{p}=0.656)$ and methoprene data points $(p=0.373 ; p=0.422)$. Significant differences were observed between the IGR slope lines $(\mathrm{p}<0.001)$. Table 1 shows the lethal concentrations (LCs) of both IGRs for $50 \%$ and $95 \%$ of Aedes aegypti.

Higher diflubenzuron concentrations caused mosquito mortality, mostly during the first $48 \mathrm{~h}$ of exposure, while lower concentrations (2 and $3 \mathrm{ppb}$ ) led to lower mortality rates and death occurred more slowly. Diflubenzuron concentrations close to LC95 promoted high mortality rates among larvae of all ages, with deaths occurring mainly during larval development (Table 2). Its action on fourth instar larvae older than $72 \mathrm{~h}$ promoted mortality mainly during the larval-pupal intermediate 
Table 1 - Lethal concentrations of diflubenzuron and metboprene for 50\% and 95\% of Aedes aegypti in Uberlândia, MG, southeastern, Brazil.

\begin{tabular}{|c|c|c|c|c|c|c|}
\hline IGRs & $\begin{array}{l}\mathrm{LC} 50 \\
(\mathrm{ppb})\end{array}$ & $95 \% \mathrm{CI}$ & $\begin{array}{l}\mathrm{LC} 95 \\
(\mathrm{ppb})\end{array}$ & $95 \% \mathrm{CI}$ & Slope & $\begin{array}{c}\text { Standard } \\
\text { error }\end{array}$ \\
\hline diflubenzuron & 5.19 & $004.59-5.79$ & 12.24 & $10.77-14.30$ & 1.92 & \pm 0.15 \\
\hline methoprene & 19.95 & $18.39-21.54$ & 72.08 & $62.85-85.29$ & 1.28 & \pm 0.08 \\
\hline
\end{tabular}

IGRs: insect growth regulators, LC: lethal concentration, CI: confidence interval, ppb: parts per billion.

Table 2 - Susceptibility of immature forms of Aedes aegyti of several ages to diflubenzuron and methoprene in Uberlândia, MG, southeastern Brazil.

\begin{tabular}{|c|c|c|c|c|c|c|}
\hline \multirow{3}{*}{$\begin{array}{l}\text { Age } \\
\text { (hours) }\end{array}$} & \multicolumn{6}{|c|}{ Mortality (\%) } \\
\hline & \multicolumn{3}{|c|}{ diflubenzuron } & \multicolumn{3}{|c|}{ methoprene } \\
\hline & control & test group & corrected* & control & test group & corrected* $^{*}$ \\
\hline$\leq 2$ & 8.9 & 96.7 & 96.4 & 7.6 & 70.9 & 68.5 \\
\hline 24 & 3.3 & 99.6 & 99.6 & 4.6 & 42.5 & 39.7 \\
\hline 48 & 9.2 & 99.6 & 99.6 & 2.9 & 57.1 & 55.8 \\
\hline $72^{* * *}$ & 3.3 & 97.5 & 97.4 & 2.1 & 91.3 & 91.1 \\
\hline 96 & 0.8 & 98.4 & 98.4 & 0.4 & 91.3 & 91.3 \\
\hline 120 & 8.8 & 98.4 & 98.2 & 1.7 & 100.0 & 100.0 \\
\hline 144 & 7.9 & 87.5 & 86.4 & 2.1 & 98.3 & 98.3 \\
\hline Pupae & 2.2 & 1.9 & 0.0 & 1.7 & 3.0 & 1.3 \\
\hline
\end{tabular}

*mortality correction according to Abbott (1925).

**early fourth instar larvae.

form. Dead larvae generally remained attached to the preceding cuticle and a larval-like abdomen was observed in those that died during the larval-pupal intermediate stage.

Most of the mortality caused by methoprene occurred after the larvae reached the pupal stage. Among the morphological abnormalities presented by dead pupae, a larva-like abdomen was the abnormality most commonly observed, accompanied in smaller numbers by pupal-adult intermediate forms. Methoprene caused higher mortality when Aedes aegypti was exposed to this IGRs as early fourth instar larvae (72h old) and death occurred mostly when they had transformed into newly formed pupae (white pupae) (Table 2). The larval groups exposed to this IGR at younger ages presented a lower mortality rate and deaths occurred mainly when the pupae were older and more pigmented (black pupae). Mosquitoes exposed to diflubenzuron and methoprene only after reaching the pupal stage presented tolerance to both IGRs (Table 2). Those that emerged only partially from the exuviae in the methoprene (3.6\%) and diflubenzuron (0.7\%) experimental groups were also recorded as dead.

Concentrations close to LC95 of the two IGRs in both the technical (Tf) and commercial (Cf) formulations presented variations in their residual activity from the second week of exposure onwards (Figure 1). The Cfs of the two IGRs presented greater residual effects than did their technical counterparts, with differences of up to one week (Figure 1). Mortality caused by the Tfs of the IGRs approached that of the control groups three weeks after starting the assays and one week earlier than seen with their Cf counterparts. In the assays performed to obtain LC50 and LC95, the lower concentrations of IGRs diminished the residual effect of both IGR formulations, thus inducing mortality more slowly.

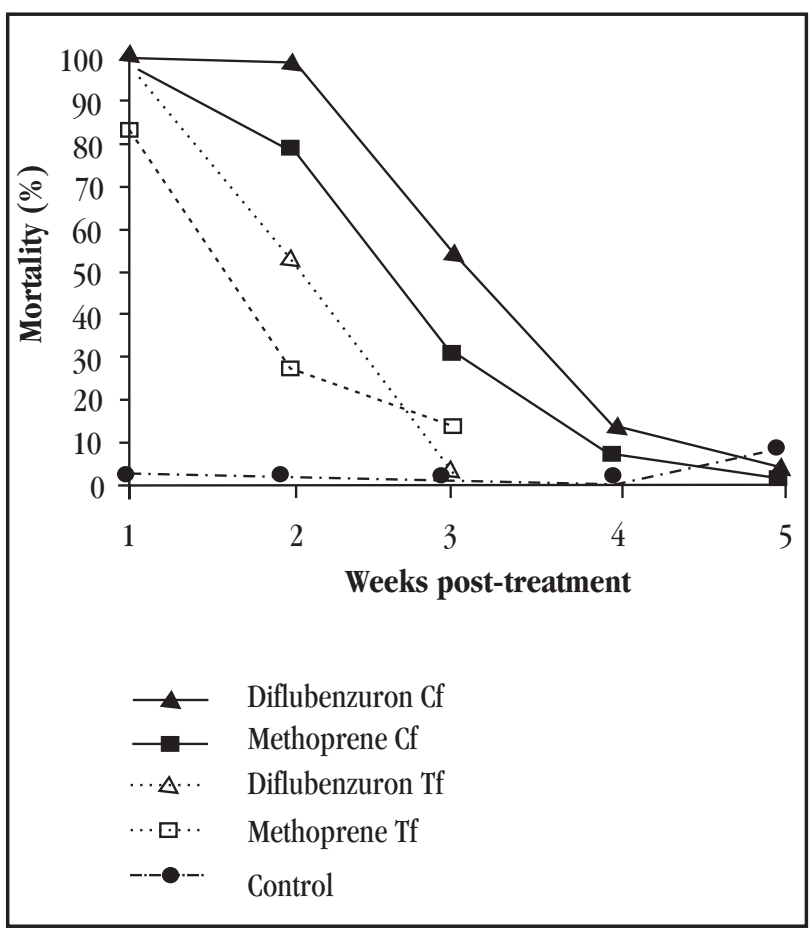

Cf: commercial formulation, Tf: technical grade formulation.

Figure 1-Residual effect of diflubenzuron at 10ppb and of methoprene at 70ppb on Aedes aegypti in Uberlândia, MG, southeastern, Brazil.

\section{DISCUSSION}

The regression analysis indicated that the susceptibility of Aedes aegypti to these IGRs is concentration-dependent, which is congruent with other studies using IGRs ${ }^{72}$. Because the reduction in residual activity over time correlates with reduced concentrations of the active ingredients of $\mathrm{IGRs}^{8}$, the data presented here on the assays of residual effects also corroborate the aforementioned assumption.

The LC50 and LC95 of diflubenzuron obtained here fell within the range of variations observed for diflubenzuron parameters reported in other studies ${ }^{70}$. However, the LC50 and LC95 of methoprene were higher than those generally reported in the literature $\mathrm{e}^{27293}$, including results reported from various other locations in Brazil, using a well-known susceptible strain ${ }^{2}$. The results from these assays may be influenced by differences in the characteristics of the water and containers, and in the temperature and humidity conditions applied in each study ${ }^{18}$. Other characteristics such as the larval instar used in the assays, the criteria for defining unviable individuals ${ }^{310}$, and the type of IGR formulation may also partially explain the variations in the results 
obtained by different authors ${ }^{22}$. Outdoor evaluations have also shown differences in the findings regarding susceptibility when compared with those obtained under laboratory conditions ${ }^{2024}$. Nevertheless, the differences in methodology adopted here do not seem sufficient to explain such a great disparity in the results. Methoprene-tolerant mosquito populations and/or exhibition of cross-resistance to conventional chemical insecticides have been recorded ${ }^{5}$. Although Braga et $\mathrm{al}^{2}$ encountered evidence of potential cross-resistance between these two insecticides in some Brazilian populations, their data indicate that it is feasible to use this IGR for controlling temephos-resistant populations. Because Aedes aegypti has been under temephos-induced pressure in Uberlândia, the expression of a cross-tolerance mechanism to methoprene would explain the LCs obtained for this IGR. Even so, studies should be undertaken to investigate this assumption.

The susceptibility of mosquito larvae of all ages to diflubenzuron and other CSI compounds is fairly well known. Exposure to sublethal concentrations result in slow development and death of a proportion of the surviving larvae as larval-pupal intermediate forms and as partially emerged imagoes 15202123 . This is due to the interference of these compounds in chitin synthesis, resulting in incapacity to cast off the exuviae and death during or soon after ecdysis ${ }^{1521}$. The stronger action of methoprene on early fourth instar larvae is well documented ${ }^{1621}$. The presence of this juvenile hormone analog when fourth instar larvae are depleted of the endogenous juvenile hormone interferes in the ecdysone-mediated metamorphosis, thereby leading to developmental disruption that results in the death of pupae or emerging imagoes ${ }^{162132}$. The morphology of the dead pupae observed here, caused by the action of this IGR, was similar to that described by Gelbič et $\mathrm{al}^{14}$ and Braga et $\mathrm{al}^{3}$.

Lower efficacy of technical IGR formulations, in relation to their commercial counterparts, has been described for mosquitoes. The decrease in the residual effects of methoprene during the second week was also observed by Nayar et $\mathrm{a}^{24}$ in Florida, USA. Lima et a ${ }^{18}$ also obtained similar results in Rio de Janeiro, Brazil. Nayar et $\mathrm{al}^{24}$ used methoprene 50ppb in their studies on residual effects, a concentrations close to what was used here.

In addition to ascertaining the validity of the assumption of tolerance to methoprene, other aspects such as evaluations under outdoor conditions ${ }^{24252931}$ using the dosages recommended by IGR manufacturers to control this mosquito should also be studied. Considering that these IGRs act differently on immature forms, thereby inhibiting the emergence of imagoes, the data presented here, together with data obtained outdoors, will show whether both or one of them can efficiently control the dengue vector in the Uberlândia region. Temperature oscillations and the characteristics of water and its containers are among the factors that may have an influence on IGR efficacy and residual activity in the field. On the other hand, manufacturers have produced commercial formulations to improve IGR efficacy under these conditions $^{17} 2124$. Their effectiveness against this mosquito, including populations resistant to organophosphate temephos, added to their relative safety for humans and environment, are sufficient reasons to pursue the utilization of IGR molecules for controlling this pest.

\section{ACKNOWLEDGEMENTS}

We thank Champion Farmoquímico Ltda and Novartis Saúde Animal Ltda for furnishing the technical and commercial products without any charge. We are also grateful to Prof. Cecília Lomônaco, of the Biological Institute of the Federal University of Uberlândia (UFU), and Jodi D.H.F. Amaral, of the Psychology Sector of the university hospital of UFU, for suggested improvements to the manuscript.

\section{REFERENCES}

1. Abbott WS. A Method of computing the effectiveness of an insecticide. Journal of Economic Entomology 18: 265-267, 1925.

2. Braga IA, Mello CB, Montella JBPL, Martins Júnior AJ, Medeiros PFV, Valle D Effectiveness of Methoprene, an insect growth regulator, against Temephosresistant Aedes aegypti populations from different Brazilian localities, under laboratory conditions. Journal of Medical Entomology 42: 830-837, 2005a.

3. Braga IA, Mello CB, Peixoto AA, Valle D. Evaluation of methoprene effect on Aedes aegypti (Diptera: Culicidae) development in laboratory conditions. Memórias do Instituto Oswaldo Cruz 100: 435-440, 2005b.

4. Carvalho MSL, Caldas ED, Degallier N, Vilarinhos PTR, Souza LCKR, Yoshizawa MAC, Knox MB, Oliveira C. Susceptibility of Aedes aegypti larvae to the insecticide temephos in the Federal District, Brazil. Revista de Saúde Pública 38: 1-6, 2004 .

5. Cornel AJ, Stanich Mam Farley D, Mulligan FS 3rd, Byde G. Methoprene tolerance in Aedes nigromaculis in Fresno County, California. Journal of the American Mosquito Control Association 16: 223-228, 2000.

6. Dame DA, Wichterman GJ, Hornby JA. Mosquito (Aedes taeniohynchus) resistance to methoprene in an isolated habitat. Journal of the American Mosquito Control Association 14: 200-203, 1998

7. Dorta DM, Chiong RT, Ortega AN, Quiñones FAG. Estudio de la sensibilidad al Dimilin (Diflubenzuron) en una cepa de Aedes (S) aegypti Linnaeus, 1762 y de Culex $(C)$ quinquefasciatus Say, 1823 criadas en el laboratório. Revista Cubana de Medicina Tropical 41:56-63, 1989.

8. The Extension Toxicology Network (Extoxnet) 2000. Pesticide Information Profiles: Methoprene. Available from: http://extoxnet.orst.edu/pips/methoprene. html. Accessing in May 142005.

9. Finney DJ. Probit analysis. Cambridge University Press, Cambridge, 1971.

10. Fournet F, Sannier C, Monteny N. Effects of the insect growth regulators OMS 2017 and Diflubenzuron on the reproductive potential of Aedes aegypti. Journal of the American Mosquito Control Association 9: 426-430, 1993.

11. Fundação Nacional da Saúde. Dengue. Instruções para pessoal de combate ao vetor: manual de normas técnicas, Ministério da Saúde, Brasília, 2001.

12. Fundação Nacional da Saúde. Programa Nacional de Controle da Dengue, Ministério da Saúde, Brasília, 2002.

13. Graf JF. The role of insect growth regulators in arthropod control. Parasitology Today 9: 471-474, 1993.

14. Gelbič I, Olejníček J, Grubhoffer L. Effects of insect hormones on hemagglutination activity in two members of the Culex pipiens complex. Experimental Parasitology 100: 75-79, 2002.

15. Grosscurt AC. Diflubenzuron: some aspects of its ovicidal and larvicidal mode of action and an evaluation of its practical possibilities. Pesticide. Science 9: 373-386, 1978.

16. Lan Q, Grier AC. Critical period for pupal commitment in the yellow fever mosquito, Aedes aegypti. Journal of Insect Physiology 50: 667-676, 2004.

17. Lima JBP, Cunha MF, Silva-Júnior RC, Galardo AKR, Soares SS, Braga IA, Ramos RP, Valle D. Resistance of Aedes aegypti to organophosphates in several municipalities in the state of Rio de Janeiro and Espírito Santo, Brazil. The American Journal of Tropical Medicine and Hygiene 88: 329-333, 2003. 
18. Lima JBP, Melo NV, Valle D. Persistence of Vectobac WDG and Metoprag S-2G against Aedes aegypti larvae using a semi-field bioassay in Rio de Janeiro, Brazil. Revista do Instituto de Medicina Tropical de São Paulo 47: 7-12, 2005.

19. Macoris MLG, Andrighetti MTM, Takaku L, Glasser CM, Garbeloto VC, Bracco JE. Resistance of Aedes aegypti from state of São Paulo, Brazil to organophosphates insecticides. Memórias do Instituto Oswaldo Cruz 98: 703-708, 2003.

20. Martins F, Silva IG. Avaliação da atividade inibidora do Diflubenzuron na ecdise das larvas de Aedes aegypti (Linnaeus, 1762) (Diptera: Culicidae). Revista da Sociedade Brasileira de Medicina Tropical 37: 135-138, 2004

21. Mulla MS. The future of insect growth regulators in vector control. Journal of the American Mosquito Control Association 11: 269-273, 1995.

22. Mulla MS, Darwazeh HA, Schreiber ET. Impact of new growth regulators and their formulations on mosquito larval development in impoundment and floodwater habitats. Journal of the American Mosquito Control Association 5:15-20, 1989

23. Mulla MS, Thavara U, Tawatsin A, Chompoosri MZ, Su T. Laboratory and field evaluation of novaluron, a new acylurea insect growth regulator, against Aedes aegypti (Diptera: Culicidae). Journal of Vector Ecology 28: 241-254, 2003.

24. Nayar JK, Arshad A, Zaim M. Effectiveness and residual activity comparison of granular formulations of insect growth regulators Pyriproxyfen and s-Methoprene against Florida mosquitoes in laboratory and outdoor conditions. Journal of the American Mosquito Control Association 18: 196-201, 2002.

25. Pawar PV, Pisale SP, Sharma RN. Effect of some new insect growth regulators on metamorphosis and reproduction of Aedes aegypti. Indian Journal of Medical Research 101: 13-18, 1995.
26. Rawlins SC, Wan J0. Resistance in some Caribbean populations of Aedes aegypti to several insecticides. Journal of the American Mosquito Control Association 11: 59-65, 1995.

27. Ritchie SA, Asnicar M, Kay BH. Acute and sublethal effects of Methoprene on some Australian mosquitoes. Journal of the American Mosquito Control Association. 13: 153-155, 1997.

28. Rodriguez MM, Bisset J, Ruiz M, Soca A. Cross-resistance to pyrethroid and organophosphorus insecticides induced by selection with temephos in Aedes aegypti (Diptera: Culicidae) from Cuba. Journal of Medical Entomology 39: 882-888, 2002.

29. Sawbi R, Klowden MJ, Sjogren RD. Sublethal effects of larval Methoprene exposure on adult mosquito longevity. Journal of the American Mosquito Control Association 8: 290-292, 1992.

30. Silva JJ, Mendes J. Effect of Diflubenzuron on immature stages of Haematobia irritans (L.) (Diptera: Muscidae) in Uberlândia, state of Minas Gerais, Brazil. Memórias do Instituto Oswaldo Cruz 97: 679-682, 2002.

31. Stark JD, Banks JE. Population-level effects of pesticides and other toxicants on arthropods. Annual Reviews of Entomology 48: 505-519, 2003

32. Wilson TG. The molecular site of action of juvenile hormone and juvenile hormone insecticides during metamorphosis: how these compounds kill insects. Journal of Insect Physiology 50: 111-121, 2004.

33. Wirth MC, Georghiou GP. Selection and characterization of temephos resistance in a population of Aedes aegypti from Tortola, British Virgin Islands. Journal of the American Mosquito Control Association 15: 315-20, 1999.

34. World Health Organization. Report of the fourth WHOPES working group meeting. Document WHO/CDS/WHOPES/2001.2. World Health Organization, Geneva, 2001. 